\title{
Zagury challenges NIH report
}

\section{Washington}

THE controversy surrounding the involvement of National Institutes of Health (NIH) researchers in AIDS vaccine trials led by Daniel Zagury, of the Pierre and Marie Curie University in Paris, is set to deepen this week with the release of a report on the affair from the institutes' Office for Protection from Research Risks (OPRR). The report, which had not been released as Nature went to press, but is understood to be sharply critical of the NIH, has drawn an angry 20-page rebuttal from Zagury and his colleague Odile Picard. Their statement rejects the OPRR's complaints as "a jumble of situations and generalizations that are false and contrary to the actual facts". Zagury believes he is being used as a pawn in the internal politics of the NIH.

The OPRR inquiry was prompted by an investigation last year by journalist John Crewdson, of the Chicago Tribune, who alleged that trials of putative AIDS vaccines in France and Zaire, involving NIH researchers, failed to comply with US Department of Health and Human Services regulations governing the use of human subjects in clinical trials (see Nature 350, 263; 1991). In a letter to the NIH in July last year, Crewdson pointed out that the trials in Zaire involved children, in clear violation of US regulations, and alleged that subjects made available to Zagury by the Zairian authorities included political prisoners. Zagury's co-workers, before the NIH suspended the collaborations in Februthe National Cancer Institute, and Bernard Moss, of the National Institute of Allergy and Infectious Diseases.

In his rebuttal of the OPRR report, ary this year, included Robert Gallo, of

Zagury says that the office made no effort to substantiate Crewdson's allegations. In any case, he argues, the French and Zairian trials were not done in collaboration with NIH researchers, so were not bound by US regulations. Although Gallo was named as a coauthor on papers describing the trials, Zagury says that he was not involved in their design or implementation. Gallo's role was limited to "an intellectual exchange" over the results and providing comments on the manuscripts, Zagury says.

The OPRR has also examined the use by Zagury of a recombinant vaccinia virus, containing genetic material from HIV, supplied by Moss for use in animal experiments. Zagury admits that he did use this strain once on eleven subjects in 1986, before Moss wrote asking Zagury not to use the strain in human clinical trials. But again, Zagury denies that this constitutes a true collaboration with Moss.

But Zagury's protests have cut little ice at OPRR. "We have heard endless and fruitless arguments about what is or is not collaboration," says office director Charles McCarthy. But that is beside the point, he says. OPRR's concern, says McCarthy, is whether the NIH obeyed its own procedures in deciding whether the research projects in question were subject to US regulations. Standard NIH procedure demands that researchers involved in clinical trials in foreign countries should submit an abstract describing the work to a review board at their own institute. It is up to this board to decide if the work must comply with US regulations. But for the collaborations with Zagury, this was rarely done, says McCarthy.

Peter Aldhous MEDICAL RESEARCH

\section{Boost for women's health}

\section{Washington}

BARELY noticed amid the row over spending on the space station, research into women's health is emerging as the big winner in US science spending. As the 1992 budget appropriations bill rumbles through Congress, tens of millions of dollars are being added for women's health research, on top of a presidential budget request for the National Institutes of Health (NIH) that was already seen as generous.

Last year, women's health research became a hot political issue, after a General Accounting Office report found that women were badly underrepresented in clinical trials sponsored by NIH (see Nature 345, 754; 1990). But a high-profile campaign by members of the Congressional Caucus for Women's Issues to raise the priority of women's health research at NIH now seems to be bearing fruit.

The additions to the presidential budget request, which are expected to yield an extra $\$ 70$ million or so for women's health projects by the time the 1992 budget is finalized, will allow a start to be made on the much-publicized Women's Health Initiative of Bernadine Healy, the new director of NIH.

Projects include studies into breast and ovarian cancer, and a ten-year study into the health of a sample of several hundred thousand women.

Peter Aldhous
Genome researchers go hog wild

\section{London}

To the long list of animals that have their own genome project, add one more: the pig. In April, researchers at 16 European laboratories began PiGMaP - a threeyear pan-European project to create a physical and genetic map of the pig genome. Supported by about 6 million ECU of European Communities and national funding, the project joins genome initiatives on worms, yeast, mice, rice and the

\section{IMAGE UNAVAILABLE FOR COPYRIGHT REASONS}

\section{Model species?}

common weed in taking advantage of the new mapping technology being developed for the human genome initiative. Pigs are a perfect species to map because they breed rapidly and their 18 chromosomes are of widely varying lengths, which are easy to sort by mechanical means, says University of Edinburgh biologist Alan Archibald, one of the project coordinators. PiGMaP's initial aim is to produce a porcine genetic map with about 150 markers, spaced 20 centimorgans apart, with which researchers can find genes that control such traits as growth speed and litter size.

C.A.

\section{EC targets zoos for crackdowns London}

HALF of the 1,000 zoos in countries of the European Communities (EC) could be closed down under a proposed $\mathrm{EC}$ rule for zoo animals passed last week. The rule closes a loophole in the 1982 Wellington Convention prohibiting the importation of endangered species to inadequate facilities, by specifying for the first time what, broadly, makes an adequate facility. Unlike the language of the convention, the new rules require that the "behavioural, social, and biological" needs of the animals be fulfilled, but they leave the specifics up to the member states. The rules require accepted standards of husbandry and veterinary care, and allow only "scientifically based breeding" - a criterion that one particular zoo owner in Belgium, who last year tried to cross a lion with a tiger, would have failed to meet. The activist group ZooWatch has estimated that, of the 1,050 zoos in Europe, as many as $\mathbf{5 0 0}$ would fail the test. 